\title{
Social Security Policy and Vindictiveness
}

\author{
by Chris Grover \\ Lancaster University \\ Sociological Research Online, 15 (2) 8 \\ $<$ http://unw.socresonline.org.uk/15/2/8.html> \\ $10.5153 /$ sro. 2111
}

Received: 20 Jul 2009 Accepted: 11 Mar 2010 Published: 30 Apr 2010

\begin{abstract}
This paper uses the work of Jock Young $(2002,2003)$ on the emergence of vindictiveness in late modern society to examine two recent developments - the withdrawal, in certain circumstances, of Housing Benefit from those people evicted for 'anti-social' behaviour and the proposed introduction of a Treatment Allowance for 'problem drug users' - in social security policy. The paper argues that while since the development of collective responses to poverty there has been concern with the behaviour of individuals in relation to paid work, we are entering a new period of social security policy where it is the general behaviour of individuals that increasingly defines access to social security benefits, rather than their financial needs.
\end{abstract}

\section{Keywords: Behaviour; Drug Use; Housing Benefit; Poor Law; Poverty; Resentment; Social Security; Treatment Allowance; Vindictiveness}

\section{Introduction}

1.1 Since the inception of collective responses to poverty what is now termed social security has been framed by economic, moral and social concerns. The main concern has been that responses to poverty, unless carefully regulated, will merely reproduce the very phenomena they attempt to address (Chambliss, 1964; Checkland and Checkland, 1974). Hence, and even during the 'golden years' of the post-World War II welfare state, it is possible to argue that social security policy has been as much, if not more, concerned with the behaviour and character of recipients as it has their economic well-being (for example, Ginsburg, 1979; Grover and Stewart, 2002; Novak, 1988; Squires, 1990).

1.2 Such an approach to understanding social welfare policies is important because it emphasises that social policies, and social security policy in particular, are framed by strategic economic and political concerns that often have very little to do with the financial needs of financially poor people. In this sense, the principles that frame social security - for instance, those of economic and social less eligibility, and individual and familial responsibility - mark distinct continuity in social security policy. However, the focus upon continuity can lead to analyses that have a distinctively ahistoric feel. This is because in its detail and delivery social security is a relatively fast-changing policy arena that, as well as longer-term concerns, is also shaped by changing configurations of economic, moral, political and social concerns.

1.3 Historically, the predominant concern with social security recipients of working age has been with their commitment to, and their attitude and their behaviour towards, securing paid employment. Such concerns continue and have been expressed over the past decade or so in strengthened powers to, according to one's perspective, 'encourage' or 'force' people into paid employment (see, for example, Grover and Stewart, 2002; Grover and Piggott, 2007). However, there has also been a broadening of behavioural concern to encompass a wider range of behaviours, most notably those related to 'anti-social' and offending behaviour. Hence, Britain is arguably at a new historical juncture in social security policy where increasingly the general behaviour of social security benefit recipients, rather than just that related to paid work, is increasingly defining access and entitlement to social security benefits. This is part of a wider trend in social policy that has been characterised as having been criminalised (Knepper, 2007; Grover, 2008; Rodger, 2008). Particularly pertinent for our purposes, Rodger (ibid: 6) notes that the criminalisation of social policy involves a:

redefinition of the aims and purposes of the welfare state: an abandonment of concerns for the alleviation of poverty, disadvantage and the meeting of human needs as ends in themselves in favour of focusing policy on criminality and criminals in order to maintain a disciplined and orderly society. 
1.4 While the idea of the criminalisation of social policy, at least in Britain, and from a social science perspective is contradictory (Grover, 2008), there can be little doubt that in recent years there has been a closer alignment of crime policy and criminal justice and social policy. In the case of social security policy, for instance, Grover (2008) argues that changes affecting young people and lone mothers over the past two decades have, at least in part, been driven by concerns with the criminality and perceived propensity for disorder of the former and, in the case of latter, the criminality of their children. However, there have also been changes in social security policy that more directly link crime and social security policy. So, for example, the 1991 Criminal Justice Act made it possible for defaulted fines to be deducted from social security benefits and the 2000 Child Support, Pensions and Social Act enabled the Department for Work and Pensions to sanction (withdraw or reduce depending upon the claimants circumstances) the social security benefits of those people breaching their community sentences. Our focus is upon more recent developments; the potential to withdraw Housing Benefit (HB) from those people evicted because of 'antisocial' behaviour and the proposed Treatment Allowance that was announced in the Green Paper, No one witten off: reforming welfare to reward responsibility (Secretary of State for Work and Pensions, 2008a) and the legislation for which was introduced in the 2009 Welfare Reform Act.

1.5 This paper examines the broadening of concerns with behaviour in social security policy through the work of Jock Young $(2002,2003)$ related to vindictiveness. The first section examines the concept of vindictiveness in recent discussions of criminal justice policy. This section argues that while the idea of vindictiveness has been developed in relationship to crime policies, the thrust of the argument is useful in understanding what might be termed the criminalisation of social security policy through attempts to modify 'anti-social' and criminal behaviour through social security policies.

1.6 The second section develops observations above that concerns with behaviour have for many years structured concerns with poverty relief policies. However, it suggests what is new in contemporary society is that state-organised forms of poverty relief are shifting from a focus upon need (even if only defined in an administrative sense) to general behaviour. The observation is made that even at the 'low point' of British social security - the Victorian poor law - it was need (destitution) that defined entitlement to relief, not behaviour. The following two sections focus upon recent policy developments - noted above - that are indicative of a vindictive drift in social security policy. The paper concludes that this shift is deeply worrying because it divorces 'anti-social' and deviant behaviour from their material and structural antecedents.

\section{Vindictiveness}

2.1 Recently vindictiveness has been discussed in relation to crime policies. It has, however, been used in various ways. In his analysis of whether vindictiveness should have a role in criminal justice, Murphy (2000: 131) takes it to mean a desire 'to get even - to seek revenge - for wrongs sustained at the hands of others'. Murphy's conceptualization of vindictiveness is problematic. It is unclear, for example, how he sees vindictiveness developing in individuals and societies. In this context, it is difficult to argue with his suggestion that vindictiveness is not necessarily an irrational response to crime, particularly for victims, but it is not difficult to contest his apparently overly-deterministic claim that vindictiveness is something that 'seems encoded in us' (ibid: 133). Indeed, if vindictiveness is 'encoded in us' there would appear to be a greater need for vigilance against it.

2.2 A more fruitful understanding of vindictiveness is contained in the work of Jock Young $(2002,2003)$. Young's thesis is that in what he conceptualises as the exclusive society of late modernity vindictiveness has fuelled the demand for, and has helped structure, penal policies that have involved the greater punishment of offenders, or, as Pratt (2000) describes it, ostentatious punishment. While Young is criticised (Yar and Penna, 2004) for overplaying the dichotomy between the inclusiveness of modern society and the exclusiveness of late modern society (a charge he denies - Young, 2004), his argument provides a trenchant critique of late modern society that, he argues, is framed by 'both economic and ontological insecurity, a discontinuity of personal and social narrative, and an exclusionary tendency towards the deviant' (Young, 2002: 465).

2.3 Central to the work of Young for many years has been the idea of relative deprivation. In his earlier work (Young, 1992; Lea and Young, 1984) he conceptualized relative deprivation as involving a view upward as a means of explaining why people engage in offending behaviour:

it is clear that parts of the poor, particularly the lower working class and certain ethnic minorities who are marginalized from the 'glittering prizes' of the wider society, experience a push towards crime that is greater than elsewhere in the structure (Young, 1992: 33).

2.4 However, in his later work Young $(2002,2003)$ argues that, equally, relative deprivation can involve a gaze downwards - 'a feeling that those who work little or not at all are getting an easy ride on your back 
and your taxes' (Young, 2002: 480) - as a means of explaining demands for, and the introduction of, increasingly punitive penal policies. It is this use of relative deprivation that is of interest to us, for it is arguably the case that not only has the relative deprivation gaze downwards resulted in demands for more punitive forms of punishments for offending behaviour, it has also resulted in more punitive approaches to social security policy in Britain aimed at changing behaviours that are considered deviant.

2.5 In explaining the role of the downwards gaze of relative deprivation in demands for greater punitiveness Young (2003: 404) draws upon the work of Svend Ranulf (1964) who was 'intrigued by the desire to punish those who do not directly harm you'. For Ranulf, the answer to the conundrum that this intrigue created lay in the concept of 'moral indignation' which he argued was not only the 'emotion behind the disinterested tendency to inflict punishment', but was also 'a kind of disguised env' (cited in Young, 2003: 404). In other words, moral indignation is not just structured by disgust with the character and behaviour of the transgressor for which they must be punished, but it is also tainted by desire. The 'respectable' do not necessarily want to be in the metaphorical shoes of the transgressor. As Young (2002: 482) notes, the 'lawyer does not want to be the junkie, the professional woman certainly [does] not want to be a teenage mother', but, as we shall see, they may desire the apparent lack of restraint by which members of what Young describes as an 'underclass' are able to live their lives. ${ }^{[1]}$

2.6 Ranulf developed his ideas about indignation through the concept of 'resentment' which Merton (1957, cited in Young, 2003: 404) argued involved a condemnation of 'what one secretly craves'. According to Young (ibid.: 404), Ranulf's innovation was to 'tie the source of envy to restraint and self-discipline'. This is an important point, for Young (2002: 481) argues that to 'survive in the late modern world demands a great deal of effort, self-control, restraint'.

2.7 However, Young extends the arguments of Ranulf (1964) beyond the purview of the lower middle classes. Late modern society, Young $(2002,2003)$ argues, subjects large swathes of the population to relative deprivation and ontological insecurities. For many, their jobs are marked by insecurity and poor pay. The hours they work are long and familial life is often disrupted. Leisure time is something that is limited. It is these circumstances demanding restraint and self-sacrifice, Young (2003: 405) argues, that 'turns simple displeasure (a sense of unfairness) into vindictiveness'. The consequence of this Young argues is that what he defines as a structurally-constituted 'underclass' becomes an 'easy enemy' which:

at least in stereotype, [is] perceived as having their children irresponsibly early, hanging around all day with their large families, having public housing provided almost free, living on the dole, staying up late drinking and taking exotic, forbidden substances and on top of all that committing incivilities and predatory crimes against the honest citizen (Young, 2002, p. 483).

2.8 The issue here is that the 'underclass' invokes contradictory emotions. Its members 'set off', Young (2003: 205) argues, 'every trigger point of fear and desire'. In its stereotype the 'underclass' is feared because of its economic threat (it and its children have to be paid for by the 'respectable' and 'included' taxpayer); its physical threat (the perpetration of 'incivilities and predatory crimes') and its social threat (the reproduction of its burdensomeness across generations). However, the 'underclass' also invokes feelings of desire; not to have to take regular paid work and, because of this, an ability to engage in those activities (partying, drinking alcohol and doing drugs) with the abandonment that the 'underclass' seems so readily to be able to do.

2.9 The identification of an 'enemy', however, means that something must be done to address it; to tackle the perceived problems that the 'underclass' causes. Garland's (1996: 461) work that represents the criminal and deviant as being Other, as bearing "little relation to 'us"', is useful here. Garland argues that contrary to arguments that recent punitive shifts in criminal justice are the consequence of the rational, administrative functions of the state in late modern society, they are the consequence of an 'aggressive populism motivated by the desire to identify appropriate target groups and deal with them in as harsh and unpleasant manner as possible' (Hallsworth, 2000: 149).

2.10 Garland's concern is primarily with criminal behaviour, but his arguments are equally applicable to a wider range of behaviours that, while may be considered deviant, are not necessarily criminal, including those behaviours of the 'underclass' that Young $(2002,2003)$ points to as causing resentment and vindictiveness in contemporary society. The consequence - to identify and deal with harshly - are similar. While Young (2003) and others (for instance, Hallsworth, 2000; Pratt, 2000) argue that punishment for crime has become more punitive in late modern society - for Young (2003), for instance, it goes beyond the principles of neo-classical and desert-based punishment - it is possible to argue that the policy implications of vindictiveness have a wider application. This is because the elasticity of the concept of 'underclass' (Lister, 1996) means it is able to draw in, and arguably conflates, poverty with 'anti-social' and criminal behaviour (c.f. Rodger, 2008) and, according to Hannah-Moffatt (2005), conflates the needs of 
offenders with the risk of recidivism. This means the idea that vindictiveness frames the development of state policies is particularly pertinent to social security policy.

\section{Social security and behaviour}

3.1 We have noted that concern with the behaviour and character of financially poor people is an example of continuity in the history of poor relief and social security policy. In particular, there has been concern with relationships between behaviour and paid work, and ensuring that the relief of poverty does not demoralize poor people by encouraging worklessness. Such concerns were perhaps best represented in the New Poor Law introduced in 1834 that, among other things, structured poor relief through the principle of 'less eligibility'; an attempt to ensure that the position of the pauper was always lesser than that of the poorest independent labourer (Checkland and Checkland, 1974). While, because of the deprived condition of the poorest labourer this was often difficult to achieve (c.f. Henriques, 1968), poor relief was nevertheless something that was to be dreaded, to be feared in pursuit of maintaining labour discipline and what might termed 'familial discipline' (the provision for a family by its other members).

3.2 However, and despite horror stories about the operation of some local poor law unions (see for example, Henriques, 1968), what is less well recognised or discussed is that, legally, it was destitution that framed the operation of the New Poor Law. In brief, if a person was destitute, and this was proven by their approach to the poor law authorities and their subsequent enquiries, then poor law authorities had to relieve their needs. It did not matter why people were destitute, but if they were, Guardians were obliged to relieve their needs (Thane, 1978; MacKinnon, 1987; Harris, 2004). Thane (1978: 32), for instance, notes that the 'central Poor Law authority insisted throughout its history that its function was to relieve destitution, not to correct morals'. While she is right to go to on to note that 'local administrators did not always put this belief into practice' (ibid.), the important point for our purposes is that in the Victorian poor law it should have been destitution, rather than behaviour, that determined the receipt of poor relief.

3.3 Of course, social security legislation is more voluminous and complex in contemporary society than the legislation contained in the 1834 Poor Law Amendment Act. An element of this increasing complexity in recent years has been the hedging of social security policy by concerns with claimants' behaviour, rather than their needs. In contrast to the New Poor Law, often regarded as the 'low point' in social security history in Britain, it is now possible for people to be denied financial assistance altogether, or to receive a lesser rate, not because of their lack of need, but because their behaviour does not conform to what the political classes feel it should do. In brief, it is increasingly the case that the contemporary equivalent of destitute people - those who would qualify for means-tested social security benefits - can be denied them because of their commission or omission of certain acts.

3.4 As we have noted in relation to paid work this is not new. In social security policy there has been several policies from the 'genuinely seeking work test' of the 1927 Unemployment Insurance Act (see Fraser, 1984) to the Wage Stop of the post-WWII period (see Elkes, 1974). And to the more recent demands that out-of-work able-bodied people should be available for, and actively seeking, employment, as well as being fully engaged with programmes (such as the various New Deal and, from 2009, its single, 'flexible' replacement) that are supposed to aid in the transition from non-employment to employment (see, for example, Jeffs and Spence, 2000; MacDonald and Marsh, 2005). If they are judged not to be doing one of these unemployed people face having their benefit sanctioned. Such policies are objectionable because they are premised upon the classical economic argument that people will only work on the threat of poverty (see, for example, Poynter, 1969; Cowherd, 1977) and because not having paid work is defined in such approaches as an individual failure, rather than structural failure in the demand for paid labour.

3.5 In this paper though, we are concerned with a broadening of concerns with behaviour. While they are not the only examples of such developments in recent social security policy, our focus is upon the powers to sanction HB introduced in the 2007 Welfare Reform Act and the proposed introduction of a Treatment Allowance contained in the 2009 Welfare Reform Act that will be sanctioned if it is adjudged that problem drug users are not making adequate attempts to address their addictions.

3.6 It is no coincidence that in late modern society the focus is upon those activities that the 'underclass', in stereotype at least, engage in, such as, in the case of HB, partying (playing loud music, having large groups of people in their homes; drunkenness and so forth) that are covered by the 'anti-social' behaviour legislation (see Squires and Stephen, 2005) and the consumption of illicit drugs in the case of the Treatment Allowance. In terms of Young's analysis of the trend towards vindictiveness in late modern society the focus is upon those activities that while being feared may also be desired; behaviours that lay outside of the restraints required in late modern society are the focus of changing social security interventions. 
the purpose of council housing and its predecessors was always as much about changing the behaviour of the poor and shaping their conduct towards middle-class defined norms of acceptability as it was about the provision of affordable and quality housing.

4.2 However, the ways in which such concerns are expressed in legislation is not fixed (Flint, 2006). Hence, it is possible to argue that Britain is 'witnessing a reconfiguration and evolution of the governance of conduct, rather than a revolution of new approaches' (ibid.: 24). There have recently been two approaches in this reconfiguration of the governance of ('anti-social') behaviour through housing-related policies; making it easier to evict tenants through the use of probationary and demoted tenancies (Flint and Nixon, 2006; Haworth and Manzi, 1999). And, our focus, making it possible in certain circumstances to withdraw HB - a means-tested benefit that helps low income families to pay their rent - from tenants who have been evicted for acting 'anti-socially'.

4.3 It took New Labour governments seven years to get legislation passed that would sanction HB in cases of 'anti-social' behaviour. The Green Paper, Quality and Choice: a decent house for all (Department for the Environment, Transport and the Regions [DETR], 2000: para. 5.47) suggested that local authorities (who are responsible for administering HB): 'could be given the powers to reduce HB for unruly tenants as an alternative, or as part of the process of pursuing an Anti-Social behaviour Order'. However, despite a Private Members Bill, introduced by former Minister for Welfare Reform, Frank Field MP, and a White Paper (Secretary of State for the Home Department, 2003), it was not until the 2007 Welfare Reform Act that watered down legislation was introduced.

4.4 The idea in 2000 had been legislation that could have led to the sanctioning of HB for those people deemed 'unruly' (DETR, 2000). However, the eventual legislation took a different form; HB would be sanctioned, 'where a person has been evicted for anti-social behaviour and refuses to address their behaviour using the support and help offered to them' (Department for Work and Pensions [DWP], 2006: 1). This argument about sanctions for HB in cases of 'anti-social' behaviour reflects what Goldson and Jamieson (2002: 88) note as the 'double-speak' of recent New Labour governments in which 'punitive authoritarianism [is shrouded] under a cloak of benign welfarism' (ibid.). If the 'support' and 'help' offered to tenants is not taken, or judged not to be adequately engaged with by tenants, then their HB can be withdrawn for up to five years. This is a particularly harsh benefit penalty, but it was felt by the government that it was necessary in order to modify the behaviour of 'anti-social' people:

Although some other benefit sanctions remove a smaller proportion of benefit, the Government feels that if this sanction is to be effective in persuading people to take up rehabilitation, it must be set at a level sufficient to achieve this (DWP, 2006: 47).

4.5 What this quote is arguing is that unless the conditionality attached to HB is so severe that it can prevent an individual from being able to financially secure a new tenancy, there is no incentive for them to engage in behaviour modification programmes. In other words, unless the needs - the need for shelter in this case - of those evicted for 'anti-social' behaviour are left unmet, the feeling in government is that individuals will not engage with those services designed to 'help' and 'support' them. This seems to be particularly vindictive in dealing with 'anti-social' behaviour because it is using the need for shelter as leverage to get people to behave more 'pro-socially'. This is emblematic of what we have seen are wider changes. Social policy, for instance, Rodger $(2006,2008)$ argues has given up on its longer-term approach of 'social steering, aimed at encouraging people to adapt to social change by offering them fiscal and service incentives' (Rodger, 2008: 1-2) in favour of a short-term approach of ' social control through the imposition of supervisory orders and the disincentives provided by the criminal justice legislation and the withholding, or the threat of withholding, of welfare support' (Rodger, 2006: 124, original italics).

4.6 In the Regulatory Impact Assessment of the 2006 Welfare Reform Bill (DWP, 2006) it was estimated that between 70 and 80 per cent of tenants evicted for 'anti-social' behaviour would be in position where their HB could be sanctioned if they did not fully engage with the 'support' offered to them. However, the total number of tenants evicted each year for 'anti-social' behaviour is not known. The government estimates 1,500 , but this just relates to the tenants of registered social landlords and, therefore, excludes private tenants. Moreover, it may under-estimate the number of social rented tenants evicted each year. So, for instance, Pawson et al. (2005) estimate that 1,633 social rented tenants were evicted in 2002/03, an increase of 500 on the previous year. If that rate of increase has been sustained it would mean that some 5,000 social rented tenants are evicted each year because of 'anti-social' behaviour. Of those, between 3,500 and 4,000 per annum would be sanctionable if they do not take up, or are judged to not be fully engaged, in the 'support' they are offered; that is up to 4,000 tenants who will potentially face homeless because of the linkage between HB and their 'anti-social' behaviour, and/or that of their dependents or 
visitors.

\section{The Treatment Allowance}

5.1 Seddon et al. (2008: 818) argues that late modern Britain is denoted by a new drugs policy agenda, the target of which "is 'problem' drug users - most commonly users of heroin and crack-cocaine - who are assumed to be involved in acquisitive offending in order to 'feed their habit'". Seddon et al. (ibid.) compare this approach to former years, marked, they suggest, by a 'liberal pragmatism'. Only in the 'last few years', they argue, has the new drugs agenda, including policies that 'would probably be profoundly shocking to an historical observer [of drugs policy]', emerged (ibid.). They explain this through a conjoining of changing patterns of drug use (for instance, the 'normalisation' thesis (Measham et al., 1994) and the growth of 'problem' drug use) and wider structural and cultural change in the shift from modernity to late modernity. In the latter they draw upon Young's work $(1999,2002,2003)$ that has also provided the framework for this paper. Curiously though, they do not mention the emergence of vindictiveness in the development of the 'new drugs policy agenda'. However, it is the case that this aspect of Young's work is particularly relevant, for 'problem' drug users arguably cause resentments in various ways: they consume illicit drugs, and in stereotype they are involved in criminal activity and are financially supported via the social security system.

5.2 The argument here is that the Treatment Allowance is a consequence of vindictiveness, for like the changes to HB discussed in the previous section, it is being driven by behavioural concerns, rather than need, in a drive to deal with the 'problem' of drug use. The current situation is that out-of-work problem drug users claim the social security benefit that is judged to be most relevant to their circumstances (Jobseekers' Allowance (JSA) if they are considered to be capable of work; Incapacity Benefit, or for more recent claimants, Employment and Support Allowance if they are felt too incapable of work due to sickness and/or disability or Income Support if they are, for instance, a lone parent). Beyond the conditionality that is attached to these various benefits regarding being available for and attempting to get into paid work, nothing is additionally asked of drug users in terms of changing their drug using behaviour.

5.3 However, the proposed Treatment Allowance will change this, for those claimants who are 'dependent on, or have a propensity to misuse any drug' (Part 1, Section 11 of the 2009 Welfare Reform Act). While the Green and White papers (Secretary of State for Work and Pensions, 2008a, 2008b) that led to the 2009 Welfare Reform Act focused upon 'problem drug users' (users of crack cocaine and heroin) the 2009 Act allows the Secretary of State for Work and Pensions to prescribe which drugs the Treatment Allowance will apply to. In addition, the 2009 Welfare Reform Act (Part 1, Section 11) allows the 'provisions to apply in relation to alcohol'.

5.4 These developments are controversial because of the extent to which the Treatment Allowance is to be framed by benefit sanctions. All claimants will be required 'to answer questions, at a specific time and place, about their use of drugs and whether it affects their chances of finding work' (House of Commons, 2009: para 301). If there are 'reasonable grounds for suspecting that [a person] may have a drug problem which is affecting their prospect of finding work' they can be required to take a 'substance-related assessment' (ibid.: para 302). If they do not attend this without 'good cause' they can be required to take at least one drug tests to help determine whether they are dependent upon or have a 'propensity to misuse any drug' (ibid., para. 301). In addition, those people with rehabilitation plans - and the aim of the Treatment Allowance is to get more people into rehabilitation - will be required to 'submit to the treatment specified in the plan, as well as taking part in interviews, assessments and other steps which may be specified' (ibid., para. 307). If these four tasks are not engaged with to the satisfaction of the state's agents then the Treatment Allowance can be sanctioned through its withdrawal or reduction for up to 26 weeks; that is six months with a reduction in a benefit that is already widely recognized as being too low and set below the government's own measure of relative poverty (Grover, 2008), or with no income at all.

5.5 Such developments are unlikely to do much to address problem drug use that is closely related to poor material conditions. While, of course, it is not the case that all people living in poor material circumstances develop drug use problems, it is the case that such people have a greater risk of developing such a problem (Neale, 2002). So, for example, Carlen (1988), found that heroin use among her respondents who were female offenders played a 'blanking off' role in their lives which were structured by, among other things, poverty and marginalization. In this sense, the proposed Treatment Allowance is not only vindictive because it places behaviour ahead of need, but is unlikely to have the desired consequences. Making drug users poorer is unlikely to make them engage in treatment if their drug use is related to such issues in the first place.

5.6 As we have hinted, the introduction of the Treatment Allowance, at least in part, has been framed by concern with getting drug users into paid work. In this context, the Treatment Allowance was outlined in a Green Paper that was central to the development of employment policy, which even in recession remains intact, to increase the employment rate from 75 per cent in 2005 to 80 per cent (Secretary of State for 
Work and Pensions, 2005; 2008a). However, in discussion about the Treatment Allowance it is clear that its introduction is framed by a wider set of moral concerns about drug users. So, for instance, in parliament (House of Commons Debates, 2009: col. 194) the then Secretary of State for Work and Pensions, James Purnell MP, argued that the government wanted to:

make sure that people on drugs, of whom there about a third of a million in the benefits system, do not just act as a conduit for the money to go into the pockets of drug dealers. We think that people should be able to receive support and treatment, but in return for their benefits, they should be expected, if they are drug abusers, to take up that treatment precisely to break the cycle of crime and deprivation.

5.7 What we have in Purnell's speech is typical of what, as we have seen, Seddon et al. (2008) describe as a new drugs policy agenda; the conflation of 'drug abuse' with crime, or the criminalization of drug policy as they describe it. While there is not a clear-cut relationship between drug use and crime (Seddon, 2000, 2006; McSweeney et al., 2007; Bennett and Holloway, 2008), ironically statements made by politicians like Purnell discursively contribute to the idea that drug users are a dangerous Other, arguably making it more difficult for them to find paid work (Grover and Paylor, forthcoming). It is also the case that the idea of forcing drugs users into actively engaging with the Treatment Allowance is the consequence of the resentment, or more specifically a political fear of the resentment, among the public of a benefit policy that financially supports drug users. In this sense, the distinction in the political imagination between the 'deserving' and 'undeserving' can be maintained (ibid.), or, as the Green paper, No one written off (Secretary of State for Work and Pensions, 2008a: para. 2.33) noted: 'taxpayers cannot be expected to support drugdependent lifestyles'.

\section{Discussion and Conclusions}

6.1 In this paper we have focused upon two developments - the possibility of withdrawing HB from those people evicted from their homes due to 'anti-social' behaviour and the introduction of the Treatment Allowance - as being indicative of vindictiveness in contemporary social security policy. Some will undoubtedly point to other developments - for example, the above-inflationary increases in benefits for children in recent years - to dismiss the idea that social security policy is increasingly framed by vindictiveness. Such arguments, however, are problematic for several reasons.

6.2 First, such arguments ignore the number of developments in social security policy that appear to be framed by vindictiveness. We have focused upon two, but, equally, we could have examined the treatment of asylum seekers, the adults of whom receive 30 per cent less financial support compared to indigenous people as a means of attempting to deter people seeking asylum in the UK (c.f. Cunningham and Tomlinson, 2005), and failed asylum seekers who can have all welfare benefits and services withdrawn if their application is denied and they 'fail to take "reasonable steps" to leave the UK' (Cunnigham and Cunnigham, 2007: 278). Or, Part 1, Clause 24 of the 2009 Welfare Reform Act that will make it possible to reduce or withhold for four weeks the benefit of those people who have been prosecuted for, have had an administrative penalty for, or have been formally cautioned for benefit fraud. This is vindictive because it means that people will be punished twice (the criminal justice or administrative penalty and the benefit sanction) for the same offence. Similarly, Part 1, Clause 25 of the 2009 Welfare Reform Bill will mean those people convicted for violent or threatening behaviour towards Jobcentre Plus, or its contractors', staff will lose their benefit entitlement for a week.

6.3 Second, such arguments ignore the quite fundamental changes in social security policy that the developments outlined in this paper are examples of. The examples we have focused upon indicate a further move away from need as being an organising principle of social security towards the general behaviour of its recipients. In New Labour's reconstituting of what it describes as the 'active welfare state' (Hutton, 2006) it is the behaviour of individuals that is privileged, not their needs, even of the most basic kind. As Deacon (2004: 912) observes: 'The primary purpose of ... welfare conditionality is not to determine entitlement or to establish need, but to change behaviour'. While, as we have seen, in the case of labour discipline this is not new, linking benefit payments to wider considerations of behaviour - 'anti-social' behaviour and drug use in our two cases - is new.

6.4 The developments that we have discussed in this paper are aimed at changing the behaviour of the socalled 'underclass', a group (class?) of people who are deemed to be in need of being brought back into the normative fold. The recent developments in social security policy that we have focused upon are aimed at doing this; changing the behaviour of the perceived 'underclass' in order to make them more desirable as workers, but which would also socially 'include' them and those people living in the same neighbourhood upon whom the behaviour of the 'underclass' may impinge.

6.5 The use of social security benefits in what we have described as a vindictive manner can be justified 
through a number of philosophical perspectives. In the case of sanctioning HB, for instance, Deacon (2004) argues it can be justified through contractualist (that underpins New Labour's mantra of 'rights and responsibilities'), paternalistic (it is in the best interests of claimants) and mutualist (people have responsibilities to each other) approaches. It is contractualist arguments that Deacon argues is the most familiar justification for welfare conditionality in Britain. The centrality of 'rights and responsibilities' to welfare 'reform' since the 1997 election (and before) is its best expression. However, what is often overlooked in its political and policy interpretation is that its proponents (for example, White, 2003) argue that if the recipients of welfare benefits and services are expected to act in particular ways then the state also has commitments to recipients. White (2003), for instance, argues that governments must satisfy 'core commitments' which "include the elimination of 'brute luck' poverty, adequate protection against market vulnerability, the reduction of inequalities and protection against discrimination" (Deacon, 2004: 915). Given the level of inequality, the inadequacy of social security benefits and lessening social mobility, it is possible to argue, in the Britain at least, that the government is failing on most of these. The implication of this is that the imposition of greater conditionality cannot be justified.

6.6 Indeed, it is possible to argue that the developments discussed in this paper will further entrench the retreat from welfarism that has framed social policy generally, and social security policy in particular, over the past 30 years. In modern society what is now termed 'anti-social' behaviour and drug use were seen as social problems that required social responses. In contrast, in late modern society such behaviours are not tolerated among poor working class people because, as we have seen, they are seen as being the consequence of individual failings and intransigence (Young, 2002). Such developments are the consequence changing political explanations of such behaviours that are now premised upon moral authoritarian versions of communitarianism (c.f. Hughes, 1996; Jamieson, 2009) that reflect, and help to constitute, values that mean the focus of policy is 'on behaviour rather than wider social and economic forces' (Rodger, 2008: 6).

6.7 Such observations are particularly problematic because if what used to be considered social problems are pathologised, the implication, as expressed for instance in mutualist approaches to conditionality (see Selznick, 1988; Deacon, 2004 for discussion), is that it does not matter how poor people are, they can, and should, always, be expected to act 'pro-socially'. It would appear that the New Labour subscribes to such ideas, but through Christian Socialism (Deacon, 2000). Hence, it appears that New Labour have very few problems with threatening or actually impoverishing further some of the poorest people in society if they are held to not be acting 'pro-socially'. The impoverishment (less income and/or homeless) is the social security consequence of the vindictiveness that Young $(2002,2003)$ writes. The tautological reasoning of benefit sanctions - that their application demonstrates the moral ineptitude of the individual - merely acts to justify poverty and inequality. If only individuals were willing to be 'included' by adjusting their behaviour, they would not face the economic precariousness that they do. The problem here is the way that this approach decontextualises 'anti-social' behaviour and drug use from their material context. Both are related to structural factors; to:

an underclass left stranded by the needs of capital on housing estates either in the inner-city, or on its periphery; those who because of illiteracy, family pathology, or general disorganisation [are] excluded from citizenship, whose spatial vistas [are] those of constant disorder and threat; and also [are] the recipients of stigma from the wider world of respectable citizens (Young, 2002: 465).

6.8 The recent developments in social security policy we have discussed in this paper will at both a practical and symbolic level exacerbate the exclusion and stigma faced by those engaged in 'anti-social' behaviour and perceived problem drug use. In this sense, attempts at 'including' them by changing the conditionality regime of social security benefits are likely to be felt by the poorest and most vulnerable as exclusionary (c.f. Young, 2002).

6.9 For Young (2002), in late modern society the welfare state has become implicated in the framing of the poor working class as a morally inept and financially burdensome 'underclass' that need to be remoralised not only for its own benefit, but also for that of wider society. However, the developments that we have discussed in this paper have been portrayed by recent governments as being means of defending the provisions of state-sponsored welfare provision. So, for instance, in arguing for sanctions to be applied to HB for those people evicted from their homes because of 'anti-social' behaviour the then Secretary of State for Work and Pensions, John Hutton MP argued:

An active welfare state, with rights and responsibilities at its heart, must send a clear signal to those evicted for anti-social behaviour that they are at the end of the line and cannot simply expect to move to another property and continue their bad behaviour at the expense of decent hard-working families. That would serve only to undermine public confidence in our welfare system (House of Commons Debates, 2006, col. 627). 
6.10 Hutton is clearly locating the need for welfare 'reform' in the political class's perceptions of the public's interpretation of existing forms of social security benefits. The fear is that unless the conditionality of welfare benefits and services are developed the resentments of the public - the 'decent', the 'hard-working' at having to pay for those Othered by such discourses (the 'indecent' and the 'feckless') will become so acute that support for welfare provision will collapse. In our framework of analysis Hutton's comments confirms that vindictiveness, at least in part, is helping to shape the future of social security policy, for it is the perceived resentment of the 'respectable' in supporting the deviant and 'anti-social' that is helping to drive the conditionality agenda. This is particularly worrying because it would appear that for policy makers and politicians it is only through the application of benefit sanctions that their perceptions of the public's resentment at having to support the 'underclass' can be satisfied. There is a perverse logic here, for it appears that financial help for the poorest people in society - those who require collective responses to poverty - can only garner support by threatening to, and actually making, them poorer.

\section{Notes}

${ }^{1}$ The use of the concept 'underclass' is controversial for at least two reasons. First, because of the association of its behavioural and cultural versions with the political right in the UK and the USA (for instance Murray, 1990, 1994) and, secondly, because it is structured through a number of empirical problems that make its central arguments about the development of an 'underclass' in Britain difficult to sustain (see for, example, Lister, 1990; Morris, 1993; Alcock, 1994; David, 1994). However, while dismissing cultural versions of 'underclass', Young (2002) argues that in a mediated stereotype the concept of 'underclass' helps to inform feelings of vindictiveness because it constructs the 'underclass' as an 'Other, as a group with defective norms who contrast with the normal majority' (Young, 2002: 469).

\section{Acknowledgements}

The author first developed this paper while a visiting Professor at Ritsumeikan University, Kyoto. He would like to thank the anonymous referees for their helpful comments on an earlier draft.

\section{References}

ALCOCK, P. (1994) 'Back to the Future: Victorian Values for the 21 st Century', in C. Murray, P. Alcock, M. David, M. Phillips and S. Slipman, Underclass: The Crisis Deepens, Choice in Welfare Series No. 20, London: Institute for Economic Affairs Health and Welfare Unit.

BENNETT, T. and HOLLOWAY, K. (2008) 'Chain Reaction', Druglink, vol. 23, no. 2, pp. 6-7.

CARLEN, P. (1988) Women, Crime and Poverty. Buckingham: Open University Press.

CHAMBLISS, W. (1964) 'A sociological analysis of the law of vagrancy', Social Problems, vol. 12: pp. 6777. [doi:10.1525/sp.1964.12.1.03a00070]

CHECKLAND, S. and CHECKLAND, E. (1974) The Poor Law Report of 1834 . Harmondsworth: Penguin.

COWHERD, R. (1977) Political Economists and the English Poor Laws. A Historical Study of the Influence of Classical Economics on the Formation of Social Welfare Policy. Athens: Ohio University Press.

CUNNINGHAM J. and CUNNINGHAM, S. (2007) "'No choice at all': Destitution or deportation? A commentary on the implementation of Section 9 of the Asylum and Immigration (Treatment of Claimants, etc.) Act 2004", Critical Social Policy, vol. 27, no. 2, pp. 277-298. [doi:10.1177/0261018307065718]

CUNNINGHAM, S. and TOMLINSON, J. (2005) "'Starve them out': does every child really matter? A commentary on Section 9 of the Asylum and Immigration (Treatment of Claimants, etc.) Act, 2004", Critical Social Policy, vol. 25, no. 2, pp. 253-275. [doi:10.1177/0261018305051330]

DAVID, M. (1994) 'Fundamentally Flawed', in C. Murray, P. Alcock, M. David, M. Phillips and S. Slipman, Underclass: The Crisis Deepens, Choice in Welfare Series No. 20, London: Institute for Economic Affairs Health and Welfare Unit.

DEACON, A. (2000) 'Learning from the US? The influence of American ideas upon 'new Labour' thinking on welfare reform', Policy and Politics, vol. 28, no. 1, pp. 5-18. [doi:10.1332/0305573002500794] 
DEACON, A. (2004) 'Justifying Conditionality: the Case of Anti-social Tenants, Housing Studies, vol. 19, no. 6, pp. 911-926. [doi:10.1080/0267303042000293008]

DETR (2000) Quality and Choice: a decent home for all . London: Department for the Environment, Transport and Regions.

DWP (2006) Welfare Reform Bill 2006 - Regulatory Impact Assessment, <http://www.dwp.gov.uk/welfarereform/docs/WelfareReformRIA.pdf>.

ELKES L. (1974) The Wage Stop: Poor By Order . Poverty Pamphlet 17. London: Child Poverty Action Group.

FLINT, J. ( 2006 ) 'Housing and the new governance of conduct' in J. Flint, Housing, urban governance and anti-social behaviour: Perspectives, policy and practice. Bristol: Policy Press.

FLINT, J. and NIXON, J. (2006) ' Governing neighbours: Anti-social behaviour orders and new forms of regulating conduct in the UK' ', Urban Studies, vol. 43 , no. 5/6, pp. 939- 955.

FRASER, D. (1984) The Evolution of the British Welfare State. 2 nd edition. Basingstoke: Macmillan.

GARLAND, D. (1996) 'The limits of the sovereign state: strategies of crime control in contemporary society', British Journal of Criminology, vol. 36, no. 4, pp. 445-71.

GINSBURG, N. (1979) Class, Capital and Social Policy . London: Macmillan.

GOLDSON, B. and JAMIESON, J. (2002) ' Youth crime, the 'parenting deficit' and state intervention: A contextual critique ' Youth Justice, vol. 2 , no. 2 , pp. 82-99.

GROVER, C. (2008) Crime and Inequality. Cullompton: Willan.

GROVER, C. and PAYLOR, I. (forthcoming) 'No one written off? Welfare, work and problem drug use', Drugs: Education, Prevention and Policy.

GROVER, C. and PIGGOTT, L. (2007) 'Social security, employment and incapacity benefit: Critical reflections on A New Deal for Welfare', Disability and Society, vol. 22, no. 7, pp. $733-746$.

[doi:10.1080/09687590701659584]

GROVER, C. and STEWART, J. (2002) The Work Connection: the role of social security in regulating British economic life. Basingstoke: Palgrave.

HALLSWORTH, S. (2000) 'Rethinking the Punitive Turn', Punishment and Society, vol. 2, no. 2, pp. 145-60. [doi:10.1177/14624740022227926]

HANNAH-MOFFATT, K. (2005) 'Criminogenic needs and the transformative risk Subject. Hybridizations of risk/need in penality', Punishment and Society, vol. 7, no. 1, pp. 29-51. [doi:10.1177/1462474505048132]

HARRIS, B. (2004) The Origins of the British Welfare State. Social Welfare in England and Wales, 1800-1945, Basingstoke: Palgrave Macmillam.

HAWORTH, A. and MANZI, T. (1999) "Managing the 'underclass': Interpreting the moral discourse of housing management", Urban Studies, vol. 36<, no. 1, pp. 153-65.

HENRIQUES, U. (1968) 'How Cruel was the Victorian Poor Law?', The Historical Journal, vol. 11, no. 2, pp. 365-371. [doi:10.1017/S0018246X00002065]

HOUSE OF COMMONS (2009) Welfare Reform Bill Explanatory Notes. Bill 8-En 54/5. London: The Stationery Office.

HOUSE OF COMMONS DEBATES (2006) Welfare Reform Bill. vol. 449, cols. 616-707.

HOUSE OF COMMONS DEBATES (2009) Welfare Reform Bill. 27 January, issue no. 2156,

<http://www.publications. parliament.uk/pa/cm200809/cmhansrd/cm090127/debtext/90127-0008.htm>.

HUGHES, G. (1996) 'Communitarianism and law and order', Critical Social Policy, vol. 16, no. 4, pp. 17-41.

HUTTON, J. (2006) The Active Welfare State: Matching Rights and Responsibilities, speech to the Work Foundation, 16 January, <http://www.dwp.gov.uk/aboutus/2006/16_01_06.asp>. 
JAMIESON, J. (2009) 'In Search of Youth justice', in K. Broadhurst, C. Grover and J. Jamieson (ed.) Critical Perspectives on Safeguarding Children. Oxford: Wiley-Blackwell.

JEFFS, T. and SPENCE, J. (2000) 'New Deal for Young People: Good deal or poor deal?', Youth and Policy, no. 66 , pp. 34-61.

KNEPPER, P. (2007) Criminology and Social Policy . London: Sage.

LEA, J. and YOUNG, J. (1984) What is to be done about law and order? Crisis in the Eighties . Harmondsworth: Penguin.

LISTER, R (1990) The Exclusive Society. Citizenship and the Poor. London: Child Poverty Action Group.

LISTER, R (1996) 'Introduction', in R. Lister (ed.) Charles Murray and the Underclass. The Developing Debate. Choice in Welfare No. 33. London: Institute of Economic Affairs Health and Welfare Unit.

MACDONALD, R. and MARSH, J. (2005) Disconnected Youth?. Basingstoke: Palgrave.

MACKINNON, M. (1987) 'English Poor Law Policy and the Crusade Against Outrelief', The Journal of Economic History, vol. 47, no. 3, pp. 603-625.

MCSWEENEY, T., HOUGH, M. and TURNBULL, P. (2007) 'Drugs and Crime: Exploring the Links', in M. Simpson, T. Shildrick, and R. McDonald, (eds.), Drugs in Britain, Basingstoke: Palgrave.

MEASHAM, F., NEWCOMBE, R. and PARKER, H. (1994) 'The Normalization of Recreational Drug Use amongst Young People in North-West England', British Journal of Sociology , vol. 45, no. 2, pp. 287-312.

MORRIS, L. (1993) 'Is There a British Underclass', International Journal of Urban and Regional Research , vol. 17 , no. 3, pp. 404-412.

MURPHY, J. (2000) 'Two cheers for vindictiveness', Punishment and Society, vol. 2, no. 2, pp. 131-143.

MURRAY, C. (1990) The Emerging British Underclass. London: Institute of Economic Affairs Health and Welfare Unit.

MURRAY, C. (1994) Underclass: The Crisis Deepens. London: Institute of Economic Affairs Health and Welfare Unit.

NEALE, J. (2002) Drug Users in Society. Basingstoke: Palgrave.

NOVAK, T. (1988) Poverty and the State. An Historical Sociology . Milton Keynes: Open University Press.

PAWSON, H., FLINT, S. and SCOTT, S. (2005) The use of possession actions and evictions by social landlords. Wetherby: Office of the Deputy Prime Minister.

POYNTER, J. (1969) Society and Pauperism. English Ideas on Poor Relief 1795-1834 . London: Routledge and Kegan Paul.

PRATT, J. (2000) 'Emotive and Ostentatious Punishment: Its Decline and Resurgence

in Modern Society', Punishment and Society, vol. 2, no. 4, pp. 417-40.

RANULF, S. (1964) Moral Indignation and Middle Class Psychology. New York: Schocken.

RODGER, J. (2006) 'Antisocial families and withholding welfare support', Critical Social Policy, vol. 26, no. 1, pp. 121-143.

RODGER, J. (2008) Criminalising Social Policy: Anti-social behaviour and welfare in a de-civilised society . Cullompton: Willan.

SECRETARY OF STATE FOR THE HOME DEPARTMENT (2003) Respect and Responsibility - Taking a Stand Against Anti-Social Behaviour. Cm 5578. London: The Stationery Office.

SECRETARY OF STATE FOR WORK AND PENSIONS (2005) Department for Work and Pensions Five Year Strategy. Opportunity and security throughout life. Cm 6447. Norwich: The Stationery Office.

SECRETARY OF STATE FOR WORK AND PENSIONS (2008a) No one written off: reforming welfare to reward responsibility. $\mathrm{Cm}$ 7363. Norwich: The Stationery Office. 
SECRETARY OF STATE FOR WORK AND PENSIONS (2008b) Raising expectations and increasing support: reforming welfare for the future. $\mathrm{Cm}$ 7506. London: The Stationery Office.

SEDDON, T. (2000) 'Explaining the drug-crime link: theoretical, policy and research issues', Journal of Social Policy, vol. 29, no. 1, pp. 95-107.

SEDDON, T. (2006) 'Drugs, Crime and Social Exclusion: Social Context and Social Theory in British DrugsCrime Research', British Journal of Criminology, vol. 46, no. 4, pp. 680-703.

SEDDON, T., RALPHS, R. and WILLIAMS, L. (2008) 'Risk, Security and the 'Criminalisation of British Drug Policy', British Journal of Criminology, vol. 48, no. 6, pp. 818-834.

SELZNICK, P. (1988) Social justice: a communitarian perspective, in A. Etzioni (ed.), The Essential Communitarian Reader. Oxford: Rowman and Littlefield.

SQUIRES, P. (1990) Anti-Social Policy: Welfare, Ideology and the Disciplinary State. Hemel Hempstead: Harvester-Wheatsheaf.

SQUIRES, P. and STEPHEN, D. (2005) Rougher Justice: Anti-social behaviour and young people . Cullompton: Willan.

THANE, P. (1978) 'Women and the Poor Law in Victorian and Edwardian England', History Workshop Journal, vol. 6 , no. 1 , pp. 29-51.

WHITE, S. (2003) The Civic Minimum. Oxford: Oxford University Press.

YAR, M. and PENNA, S. (2004) 'Between Positivism and Post-modernity?: Critical Reflections on Jock Young's The Exclusive Society', British Journal of Criminology, vol. 44, no. 4, pp. 533-549.

YOUNG, J. (1992) 'Ten points of realism', in J. Young and R. Matthews (eds.), Rethinking Criminology: the realist debate. London: Sage.

YOUNG, J. (1999) The Exclusive Society. London: Sage.

YOUNG, J. (2002) 'Crime and Social Exclusion', in M. Maguire, R. Morgan and R. Reiner (eds.), The Oxford Handbook of Criminology. 3 rd edition. Oxford: Oxford University Press.

YOUNG, J. (2003) 'Merton with energy, Katz with structure: The sociology of vindictiveness and the criminology of transgression', Theoretical Criminology, vol. 7, no. 3, pp. 389-414.

YOUNG, J. (2004) 'Crime and the Dialectics of Inclusion/Exclusion: Some Comments on Yar and Penna', British Journal of Criminology, vol. 44, no. 4, pp. 550-561. 